\title{
Borrelia carolinensis sp. nov., a novel species of the Borrelia burgdorferi sensu lato complex isolated from rodents and a tick from the south-eastern USA
}

Correspondence

Nataliia Rudenko

natasha@paru.cas.cz

\author{
Nataliia Rudenko, ${ }^{1,2} \dagger$ Maryna Golovchenko, ${ }^{1,2} \dagger$ Libor Grubhoffer $^{1}$ \\ and James $\mathrm{H}$. Oliver, $\mathrm{Jr}^{2}$ \\ ${ }^{1}$ Biology Centre, Institute of Parasitology AS CR, and Faculty of Sciences, University of South \\ Bohemia, České Budějovice 37005, Czech Republic
}
${ }^{2}$ Georgia Southern University, James H. Oliver, Jr. Institute of Arthropodology and Parasitology, Statesboro, GA 30460-8056, USA

\begin{abstract}
A group of 16 isolates with genotypic characteristics different from those of known species of the Borrelia burgdorferi sensu lato complex were cultured from ear biopsies of the rodents Peromyscus gossypinus and Neotoma floridana trapped at five localities in South Carolina, USA, and from the tick Ixodes minor feeding on $N$. floridana. Multilocus sequence analysis of members of the novel species, involving the 16S rRNA gene, the 5S-23S ( $r r f-r r l)$ intergenic spacer region and the flagellin, $\operatorname{sp} A$ and $p 66$ genes, was conducted and published previously and was used to clarify the taxonomic status of the novel group of $B$. burgdorferi sensu lato isolates. Phylogenetic analysis based on concatenated sequences of the five analysed genomic loci showed that the 16 isolates clustered together but separately from other species in the B. burgdorferi sensu lato complex. The analysed group therefore represents a novel species, formally described here as

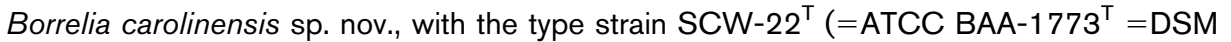
$\left.22119^{\mathrm{T}}\right)$.
\end{abstract}

Borrelia burgdorferi was first isolated from the tick Ixodes scapularis (formerly known as Ixodes dammini) by Burgdorfer et al. (1982). Later, Johnson et al. (1984) identified this spirochaete as a novel species belonging to the genus Borrelia. Since this first discovery, a large number of Borrelia isolates, in general referred to as Borrelia burgdorferi sensu lato, has been obtained from various vertebrate species, including humans. Seventeen species of spirochaetes from this complex are recognized globally today: Borrelia burgdorferi sensu stricto (Johnson et al., 1984), B. afzelii (Canica et al., 1993), 'B. andersonii' (Marconi et al., 1995), 'B. bissettii' (Postic et al., 1998), 'B. californiensis' (Postic et al., 2007), B. garinii (Baranton et al., 1992), B. japonica (Kawabata et al., 1993), B. lusitaniae (Le Fleche et al., 1997), B. sinica (Masuzawa et al., 2001), B. spielmanii (Richter et al., 2006), B. tanukii (Fukunaga et al., 1996a), B. turdi (Fukunaga et al., 1996a) and B. valaisiana (Wang et al., 1997) and the recently described 'Borrelia yangtze' (Chu et al., 2008), 'B. bavariensis' (Margos et al.,

†These authors contributed equally to this work.

Abbreviation: MLSA, multilocus sequence analysis.

The GenBank/EMBL/DDBJ accession numbers for the sequences of the 16S rRNA gene, 5S-23S intergenic spacer region and flagellin, $p 66$ and $\operatorname{OSpA}$ genes of strain SCW-22 ${ }^{\top}$ are respectively EU085407, EU072436, EU076496, EU076512 and EU085398.
2009), B. americana (Rudenko et al., 2009b) and ' $B$. carolinensis' (Rudenko et al., 2009a).

In a recent study, we reported the isolation of 16 strains belonging to a novel group of the B. burgdorferi sensu lato complex that we named 'Borrelia carolinensis' (Rudenko et al., 2009a). Nine strains were isolated from ear biopsies of the cotton mouse Peromyscus gossypinus (strains SCCH6, SCCH-10, SCW-13, SCW-14, SCW-19, SCW-21, SCGT6, SCGT-21 and SCSC-1), six strains were isolated from ear biopsies of the eastern woodrat Neotoma floridana (strains SCCH-11, SCCH-12, SCJ-1, SCJ-5, SCJ-6 and SCGT-18) and one strain, SCW $-22^{\mathrm{T}}$, was cultured from the hard tick Ixodes minor, that was feeding on $N$. floridana.

Borreliae from ear tissues were cultured using standard procedures in BSK-H medium that contained $0.15 \%$ agarose, rifampicin, phosphomycin and amphotericin B (Oliver et al., 2000). The cultures were incubated in $5 \%$ $\mathrm{CO}_{2}$ at $33-34{ }^{\circ} \mathrm{C}$ and stored at $-80{ }^{\circ} \mathrm{C}$ after cell densities reached $2 \times 10^{6}$ spirochaetes $\mathrm{ml}^{-1}$. The presence of a single Borrelia species in each culture was confirmed by repeated amplification of selected loci and bidirectional sequencing of PCR products. Multilocus sequence analysis (MLSA) was conducted using standard procedures and previously described primers (Guy \& Stanek, 1991; Postic et al., 1994; Fukunaga et al., 1996b; Thompson et al., 1997; Posada \& 
Crandall, 1998; Le Fleche et al., 1997; Guindon \& Gascuel, 2003; Güner et al., 2003; Clark et al., 2005). Results of genetic and phylogenetic analyses have been presented in detail previously (Rudenko et al., 2009a). Briefly, MLSA revealed that the newly described isolates were highly homogeneous between themselves but distant from known spirochaete species. Unique RFLP patterns were detected for the 5S-23S intergenic spacer region and flagellin gene and unique, phylogenetically significant signature nucleotides (Marconi et al., 1992) were identified in the 16S rRNA gene sequences of ' $B$. carolinensis' strains. Sequences from five genomic loci of all 16 strains of ' $B$. carolinensis' have been deposited in GenBank under the accession numbers EU085403-EU085418 for the 16S rRNA gene, EU072425EU072440 for the 5S-23S ( $r r f-r r l$ ) intergenic spacer region, EU076485-EU076500 for the fla gene, EU076501EU076516 for p66 and EU085387-EU085402 for ospA. Reference sequences of known Borrelia species were downloaded from GenBank.

The results of MLSA and phylogenetic analysis clearly showed that the ' $B$. carolinensis' strains constituted a novel taxon in the B. burgdorferi sensu lato complex (Rudenko et al., 2009a). P. gossypinus and N. floridana are shown to be the primary reservoir hosts of ' $B$. carolinensis'. The geographical distribution of the two rodent species may be used as indirect evidence of the possible distribution of ' $B$. carolinensis' in the USA (Oliver, 1996). The geographical range of $P$. gossypinus extends northward from the Gulf of Mexico to south-eastern Virginia and southern Illinois, and westward from the Atlantic Ocean to eastern Texas and south-eastern Oklahoma. The species appears to be absent from the southern Appalachians. N. floridana occurs throughout Mississippi; its geographical range includes South Dakota and Colorado, eastern Texas, east and central Florida, north to the western and Piedmont areas of Maryland and then west following the Appalachian Mountains (Guilliams \& Francl, 2008). Identification of well-established populations of ' $B$. carolinensis' was perhaps predetermined by natural factors that exist in the southeastern United States.

\section{Description of Borrelia carolinensis sp. nov.}

Borrelia carolinensis (ca.ro.li.nen'sis. N.L. fem. adj. carolinensis of or belonging to Carolina, referring to South Carolina, USA, where the organism was first isolated).

Morphology is as described previously for the genus (Barbour \& Hayes, 1986). Cultural properties are as described for B. burgdorferi sensu lato (Johnson et al., 1984). Can be differentiated from other species of the $B$. burgdorferi sensu lato complex by MLSA of five genomic loci and phylogenetic analysis. The RFLP pattern of the 5S$23 \mathrm{~S}$ intergenic spacer region consists of four fragments after digestion by MseI (107, 67, 52 and $27 \mathrm{bp})$ and three fragments after digestion by $\operatorname{DraI}(173,53$ and $27 \mathrm{bp})$. Strains exhibit the following unique signature nucleotides in the 16S rRNA gene: $A_{171}, T_{203}, C_{323}, C_{1028}$ and $G_{1111}$.
Strain SCJ-1 also has a unique signature nucleotide: $\mathrm{G}_{990}$. The RFLP pattern of the partial fla gene consists of five fragments after digestion by $D d e \mathrm{I}(221,117,78,45$ and $27 \mathrm{bp}$ ) and two fragments after digestion by CelII (365 and 123 bp); strain SCGT-18 lacks the CelII restriction site and has only four fragments after digestion by DdeI $(221,117$, 78 and $72 \mathrm{bp}$ ). Strains have been isolated from the rodents Peromyscus gossypinus and Neotoma floridana trapped at five localities in South Carolina, USA, as well as a single strain isolated from a hard tick.

The type strain, SCW $-22^{\mathrm{T}}$ (=ATCC BAA $-1773^{\mathrm{T}}=\mathrm{DSM}$ $22119^{\mathrm{T}}$ ), was isolated from a male Ixodes minor tick fed on N. floridana.

\section{Acknowledgements}

This research was supported in part by the National Institutes of Health (NIH) (grant R37AI-24899) and a cooperative agreement from the Centers for Disease Control and Prevention (CDC) (U50/ CCU410282). This work was also partially supported by the Czech Ministry of Education (grants MSM 6007665801 and LC06009), the Institute of Parasitology AS CR (Z60220518) and the Czech Science Foundation (grant 206/09/1782).

\section{References}

Baranton, G., Postic, D., Saint Girons, I., Boerlin, P., Piffaretti, J.-C., Assous, M. \& Grimont, P. A. D. (1992). Delineation of Borrelia burgdorferi sensu stricto, Borrelia garinii sp. nov., and group VS461 associated with Lyme borreliosis. Int J Syst Bacteriol 42, 378-383.

Barbour, A. G. \& Hayes, S. F. (1986). Biology of Borrelia species. Microbiol Rev 50, 381-400.

Burgdorfer, W., Barbour, A. G., Hayes, S. F., Benach, J. L., Grunwaldt, E. \& Davis, J. P. (1982). Lyme disease - a tick-borne spirochetosis? Science 216, 1317-1319.

Canica, M. M., Nato, F., du Merle, L., Mazie, J. C., Baranton, G. \& Postic, D. (1993). Monoclonal antibodies for identification of Borrelia afzelii sp. nov. associated with late cutaneous manifestations of Lyme borreliosis. Scand J Infect Dis 25, 441-448.

Chu, C.-Y., Liu, W., Jiang, B.-G., Wang, D.-M., Jiang, W.-J., Zhao, Q.-M., Zhang, P.-H., Wang, Z.-X., Tang, G.-P. \& other authors (2008). Novel genospecies of Borrelia burgdorferi sensu lato from rodents and ticks in southwestern China. J Clin Microbiol 46, 3130-3133.

Clark, K., Hendricks, A. \& Burge, D. (2005). Molecular identification and analysis of Borrelia burgdorferi sensu lato in lizards in the southeastern United States. Appl Environ Microbiol 71, 26162625.

Fukunaga, M., Hamase, A., Okada, K. \& Nakao, M. (1996a). Borrelia tanukii sp. nov. and Borrelia turdae sp. nov. found from ixodid ticks in Japan: rapid species identification by $16 \mathrm{~S}$ rRNA gene-targeted PCR analysis. Microbiol Immunol 40, 877-881.

Fukunaga, M., Okada, K., Nakao, M., Konishi, T. \& Sato, Y. (1996b). Phylogenetic analysis of Borrelia species based on flagellin gene sequences and its application for molecular typing of Lyme disease borreliae. Int J Syst Bacteriol 46, 898-905.

Guilliams, B. \& Francl, K. (2008). Neotoma floridana - eastern woodrat. In Animal Diversity Web. Ann Arbor, MI: University of Michigan Museum of Zoology. http://animaldiversity.ummz.umich. edu/site/accounts/information/Neotoma_floridana.html 
Guindon, S. \& Gascuel, O. (2003). A simple, fast, and accurate algorithm to estimate large phylogenies by maximum likelihood. Syst Biol 52, 696-704.

Güner, E. S., Hashimoto, N., Takada, N., Kaneda, K., Imai, Y. \& Masuzawa, T. (2003). First isolation and characterization of Borrelia burgdorferi sensu lato strains from Ixodes ricinus ticks in Turkey. J Med Microbiol 52, 807-813.

Guy, E. C. \& Stanek, G. (1991). Detection of Borrelia burgdorferi in patients with Lyme disease by the polymerase chain reaction. J Clin Pathol 44, 610-611.

Johnson, R. C., Schmidt, G. P., Hyde, F. W., Steigerwalt, A. G. \& Brenner, D. J. (1984). Borrelia burgdorferi sp. nov.: etiologic agent of Lyme disease. Int J Syst Bacteriol 34, 496-497.

Kawabata, H., Masuzawa, T. \& Yanagihara, Y. (1993). Genomic analysis of Borrelia japonica sp. nov. isolated from Ixodes ovatus in Japan. Microbiol Immunol 37, 843-848.

Le Fleche, A., Postic, D., Girardet, K., Peter, O. \& Baranton, G. (1997). Characterization of Borrelia lusitaniae sp. nov. by $16 \mathrm{~S}$ ribosomal DNA sequence analysis. Int J Syst Bacteriol 47, 921-925.

Marconi, R. T., Lubke, L., Hauglum, W. \& Garon, C. F. (1992). Speciesspecific identification of and distinction between Borrelia burgdorferi genomic groups by using $16 \mathrm{~S}$ rRNA-directed oligonucleotide probes. J Clin Microbiol 30, 628-632.

Marconi, R. T., Liveris, D. \& Schwartz, I. (1995). Identification of novel insertion elements, restriction fragment length polymorphism patterns, and discontinuous $23 \mathrm{~S}$ rRNA in Lyme disease spirochetes: phylogenetic analyses of rRNA genes and their intergenic spacers in Borrelia japonica sp. nov. and genomic group 21038 (Borrelia andersonii sp. nov.) isolates. J Clin Microbiol 33, 2427-2434.

Margos, G., Vollmer, S. A., Cornet, M., Garnier, M., Fingerle, V., Wilske, B., Bormane, A., Vitorino, L., Collares-Pereira, M. \& other authors (2009). A new Borrelia species defined by multilocus sequence analysis of housekeeping genes. Appl Environ Microbiol 75, 5410-5416.

Masuzawa, T., Takada, N., Kudeken, M., Fukui, T., Yano, Y., Ishiguro, F., Kawamura, Y., Imai, Y. \& Ezaki, T. (2001). Borrelia sinica sp. nov., a Lyme disease-related Borrelia species isolated in China. Int J Syst Evol Microbiol 51, 1817-1824.

Oliver, J. H., Jr (1996). Lyme borreliosis in the southern United States: a review. J Parasitol 82, 926-935.
Oliver, J. H., Jr, Clark, K. L., Chandler, F. W., Jr, Tao, L., James, A. M., Banks, C. W., Huey, L. O., Banks, A. R., Williams, D. C. \& Durden, L. A. (2000). Isolation, cultivation, and characterization of Borrelia burgdorferi from rodents and ticks in the Charleston area of South Carolina. J Clin Microbiol 38, 120-124.

Posada, D. \& Crandall, K. A. (1998). ModelTest: testing the model of DNA substitution. Bioinformatics 14, 817-818.

Postic, D., Assous, M. V., Grimont, P. A. D. \& Baranton, G. (1994). Diversity of Borrelia burgdorferi sensu lato evidenced by restriction fragment length polymorphism of $r r f(5 S)$ - $r r l$ (23S) intergenic spacer amplicons. Int J Syst Bacteriol 44, 743-752.

Postic, D., Ras, N. M., Lane, R. S., Hendson, M. \& Baranton, G. (1998). Expanded diversity among Californian Borrelia isolates and description of Borrelia bissettii sp. nov. (formerly Borrelia group DN127). J Clin Microbiol 36, 3497-3504.

Postic, D., Garnier, M. \& Baranton, G. (2007). Multilocus sequence analysis of atypical Borrelia burgdorferi sensu lato isolates description of Borrelia californiensis sp. nov., and genomospecies 1 and 2. Int J Med Microbiol 297, 263-271.

Richter, D., Postic, D., Sertour, N., Livey, I., Matuschka, F.-R. \& Baranton, G. (2006). Delineation of Borrelia burgdorferi sensu lato species by multilocus sequence analysis and confirmation of the delineation of Borrelia spielmanii sp. nov. Int J Syst Evol Microbiol 56, 873-881.

Rudenko, N., Golovchenko, M., Grubhoffer, L. \& Oliver, J. H., Jr (2009a). Borrelia carolinensis sp. nov., a new (14th) member of the Borrelia burgdorferi sensu lato complex from the southeastern region of the United States. J Clin Microbiol 47, 134-141.

Rudenko, N., Golovchenko, M., Lin, T., Gao, L., Grubhoffer, L. \& Oliver, J. H., Jr (2009b). Delineation of a new species of the Borrelia burgdorferi sensu lato complex, Borrelia americana sp. nov. J Clin Microbiol 47, 3875-3880.

Thompson, J. D., Gibson, T. J., Plewniak, F., Jeanmougin, F. \& Higgins, D. G. (1997). The CLUSTAL_X windows interface: flexible strategies for multiple sequence alignment aided by quality analysis tools. Nucleic Acids Res 25, 4876-4882.

Wang, G., van Dam, A. P., Le Fleche, A., Postic, D., Peter, O., Baranton, G., de Boer, R., Spanjaard, L. \& Dankert, J. (1997). Genetic and phenotypic analysis of Borrelia valaisiana sp. nov. (Borrelia genomic groups VS116 and M19). Int J Syst Bacteriol 47, 926-932. 